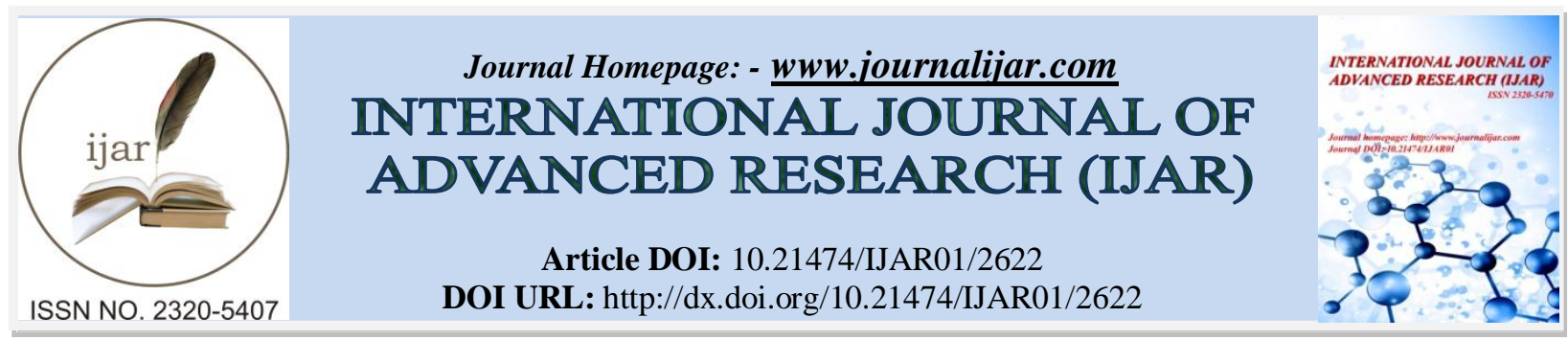

RESEARCH ARTICLE

\title{
INFLUENCE OF SELECTED TEACHER INSTRUCTIONAL STRATEGIES ON SECONDARY SCHOOLS STUDENTS' MATHEMATICS LEARNING OUTCOMES KENYA.
}

"Dr. Marble Nandwa Odhiambo ${ }^{1}$ and Dr. Duncan Wekesa Wasike ${ }^{2}$.

1. Department of Science and Mathematics Education, Masinde Muliro University of Science and Technology.

2. Department of Science and Mathematics Education, Kibabii Univerisity and to whom correspondence should be addressed.

\section{Manuscript Info}

\section{Manuscript History}

Received: 30 October 2016

Final Accepted: 29 November 2016

Published: December 2016

Key words:-

Influence, Instructional Strategies,

Attitude, Motivation

\section{Abstract}

Mathematics is a key subject which students cannot avoid if they have to lead a brighter future. Despite the introduction and implementation of different teaching methods and strategies suggested by researchers, students' motivation towards mathematics has persistently been poor. The purpose of this study was to find out the influence of selected teacher instructional strategies on students' motivation in mathematics in secondary schools. This entailed the use of Behavioral ObjectiveBased (BOB) Instructional Strategy, Peer Instruction enriched with Concept Tests (PICT), both BOB and PICT (BO-PICT) and Conventional Instruction (TI). This study investigated the relationship between the motivation of students who used BOB, PICT and BOPICT strategies and their counterparts who used TI. The theoretical framework which guided this study was social constructivism theory. This study adopted a pre-test post-test non-equivalent group design. The target population for the study was all form three students in the 38 secondary schools in Mumias sub-county. Stratified random sampling was used to select schools that took part in the study. The strata were boys' schools, girls' schools and co- educational schools. This study used disproportionate stratified sampling to select 2 schools out of 3 boys' schools by saturated sampling, 3 schools out of 10 girls' schools and 3 schools out of 25 co-education schools by simple random sampling giving a total of eight (8) schools that participated in the study. One stream selected randomly from each sampled school took part in the study. The Control group (C) used (TI), the Experimental group one (E1) used BOB Instructional Strategy, the Experimental group two (E2) used (PICT) while the Experimental group three (E3) used both BOB and PICT (BO-PICT) in the learning of mathematics. Each group (C, E1, E2, and E3) comprised of two schools selected randomly from the eight schools. Students' Motivation Questionnaire (SMQ) was used to collect the required data. The instrument was developed basing on the objective as well as variables in the theoretical model and given to experts in mathematics education to validate. The Split half technique was used to determine the reliability of the research instruments because it requires only one testing session to save on time and it eliminates 
chance error. Data were analyzed using both descriptive and inferential statistics. Results indicated that there was a significant difference in motivation between all Experimental groups (E1, E2 and E3) and the Control group (C) in favor of the Experimental groups. BOB, PICT and BO-PICT Instructional Strategies were found to be viable instructional strategies that could promote performance in mathematics. Recomemendations were made for the adoption of BOB, PICT and BO-PICT instructional strategies in the teaching of Mathematics in secondary schools. Specifically it was recommended that BO-PICT which was superior to other strategies be adopted in schools for the teaching of mathematics.

Copy Right, IJAR, 2016,. All rights reserved.

\section{Introduction:-}

The perennial problem of poor performance of students in mathematics has remained a matter for great concern to all (National Council of Teachers of Mathematics (NCTM), 2000). It has been described as a model of thinking (lji, 2008), which encourages learners to observe, reflect and reason logically about a problem and in communicating ideas making it the central intellectual discipline and a vital tool in science, technology and commerce (Imoko \& Agwagah, 2006). In the words of Salman (2005), "mathematics is a precursor of scientific discoveries and inventions". Hersh (1986) defines mathematics as ideas not as marks made with pencils or chalk, not physical triangles or physical sets. Underlying his view of mathematics is that knowing mathematics is making mathematics.

A part from the economic benefits it is argued that competence in mathematics better prepares young people for their numeracy demands of modern work places, as well as raising the overall skill levels of the work force (Kenya Institute of Education (KIE), 2002). There are also social benefits tied to improving access for larger numbers of young people to post school education and training. This explains why mathematics is one of the core courses in Kenyan Secondary Schools. Despite the recognition accorded to mathematics due to its relevance since the ancient period, Elekwa (2010) remarked that students exhibit negative attitude towards mathematics, even when they know that they need it to forge ahead in their studies and in life.

\section{Background of the Study:-}

Analysis of Kenya Certificate of Secondary Examination (KCSE) results shows that Students' performance in mathematics are consistently poor (Kenya National Examinations Council (KNEC), 2008). Many reasons have been cited for poor performance in mathematics. First, mathematics is highly abstract. It is concerned with ideas rather than objects; with the manipulation of symbols rather than objects. It is a closely-knit structure in which ideas are interrelated. Mathematical concepts are hierarchical and interconnected. Unless lower-level concepts are mastered, higher-level concepts cannot be understood.

Secondly, Butty (2001) showed that the mode of instruction, especially at the secondary school level remains overwhelmingly teacher-centered, with greater emphasis on the lecture mode of instruction and the use of textbooks than engaging students in critical thinking across subject area and applying the knowledge acquired to real-world situations which has subsequently impacted on students' performance.

Third, teaching and learning of mathematics is a complex activity and many factors determine the success of this activity. The nature and quality of instructional material, the presentation of content, the pedagogic skills of the teacher, the learning environment, the motivation of the students are all important and must be kept in view in any effort to ensure quality in teaching-learning of mathematics in an effort to improve students' performance.

Fourth, achieving improvement in mathematics teaching and learning requires seeing mathematics as multidimensional, for example including both procedures as concepts, as well as strategies, ways of reasoning, attitudes and dispositions (Kilpatrick et al 1991). Researchers emphasize the need to develop students' understanding of mathematical connections among topics, across representations, and between contextualized and decontextualized settings. Developing these connections often requires more attention to mathematical discussion and argumentation in the opportunity to struggle with challenging mathematics (Hiebert \& Grows, 2007). It also requires students to explore and engage with challenging mathematics, for example by managing the cognitive load 
(Chandler \& Sweller, 1991) and enabling a more interactive, exploratory path into difficult mathematics (Kaput et al, 2007).

Enhancing mathematics teaching and learning is therefore the most important challenge facing educators worldwide. In recent decades, there have been strong calls for change in mathematics education, and in particular for change in classroom practices. Teachers have been forced to organize instruction so that students participate in more collaborative, discussion - based activities with an eye to supporting a community of learners, rather than a set of individuals working on mathematics (NCTM, 1991). Organizing these kinds of collaborative practices, however, has proven to be very challenging (Ball, 1993).

The teacher is the most indispensable factor in effective administration of any education system (Wilkins, 2002). The role of teachers at all levels of education is emphasized that no educational system may rise above the quality of its teachers. This declaration in the policy document underscores the need for teachers' effectiveness in teaching and learning (Mitzel, 1960). Farrant (1994) conceptualized teachers' effectiveness as the managerial skills essential for enhancing classroom control and discipline. It is the teachers' competence, ability, resourcefulness, and ingenuity through effective utilization of appropriate language, methodology and available instructional materials that could bring out the best from the learners in terms of academic achievement.

In an era of standards-based reform in education, many believe that the best way to raise student academic achievement is through improved teaching (Birman et al, 2000). To that end, Porter and Brophy (1988) maintained that student learning can be improved upon only if teachers' practices are of high standard, however, they contend that many teachers are not prepared to implement practices that reflect high standards. What is more, professional development for teachers could serve to fill the gap between standards-based reform and pre-service teacher preparations (Birman et al., 2000). Unfortunately, many times the professional development provided to teachers does not adequately prepare them for the rigors of standard-based student achievement (Corcoran, 1995; DarlingHammond, 1996; Hiebert, 1999; Little 1993; Sparks \& Loucks-Horsley, 1989).

Roschelle and Singleton (2008) said that no single factor is sufficient to change mathematics education. Intrinsically, improving mathematics achievement requires paying attention to a three way relationship among teachers, students, and instructional resources (where resources include curriculum, assessment and technology). Researchers have repeatedly found out that changing one relationship (such as giving students new handled technology) requires corresponding changes in teacher - student interaction and how teachers use instructional resources to be effective (Roschelle et al, 2000).Powerful new representations only increase student understanding if teachers engage students in probing the meaning of the representations. Likewise, a change in the teacher - student interaction (such as a teacher giving students more responsibility to solve challenging mathematics problems), can be supported by giving students new tools, for example, that enables exploration of a mathematical construct in terms of actions and consequences (Bransford et al,2000). Of course, aligned and sustained teacher professional development is essential to such instructional change (Wei et al, 2009).

As revealed by the demands of the $21^{\text {st }}$ century pedagogy, studies over the past 15 years have shown over and over just how thin many teachers' knowledge is. They are simply failing to reach reasonable standards of mathematical proficiency with most of the students, and those students become nation's adults. The usual solution is to require teachers to study more mathematics. Many propose additional coursework for teachers, and some argue that elementary teachers should be specialists. But increasing the quantity of teachers' mathematics coursework will only improve on the quality of mathematics teaching if teachers learn mathematics on ways that make a difference for the skill with which they are able to do their work. The goal is not to produce teachers who know more mathematics. The goal is to improve students' learning. Teachers' opportunities to learn must equip them with the mathematical knowledge and skill that will enable them to teach mathematics effectively.

Owing to poor level of achievement in Mathematics, several approaches in teaching and learning Mathematics have been designed and practiced at one point or the other. Some of these teaching approaches are Behavioral objectiveBased and Peer Instruction enriched with Concept Tests strategies. According to Wikipedia (2010), these instructional strategies are educational technique that challenges the mantras of modern bureaucrats and shows that even the most disadvantaged children can excel, if only the schools will teach them. He described them as rigorously developed; highly scripted methods of teaching that are fast-paced and provide constant interaction between students and the teacher. Moreover, Gagnon and Maccini (2011) posit that these instruction methods are specific methods of 
teaching that focuses on what to teach in respect to the design of the curriculum and how to teach which focuses on specific teaching techniques. From literature therefore, researches have been carried out to find out the effect of different instructional practices on students' outcomes in mathematics. This study compared different instructional practices so as to come up with the most viable in the learning of mathematics; specifically in the topic of Compound Proportions and Rates of Work.

The emphasis on the use of selected teacher instructional practices in the teaching and learning of mathematics in Kenyan secondary schools becomes more urgent considering the teacher dominated approach to schooling and teaching. Most schools in Mumias sub-county are well equipped considering the fact that Mumias Sugar Company has sponsored most of them through it's cooperate social responsibility and outreach programs. Despite its exemplary performance, students' performance in mathematics in the sub-county is still wanting. Generally the overall mean score for the sub-county and the county has been greater than that of the mathematics mean in both cases. Table 1.1 hereunder shows sub-county and county mean scores as compared by the sub-county and county mathematics mean scores.

Table 1.1:- County and sub-County Mathematics Mean scores since 2012

\begin{tabular}{|l|l|l|l|l|}
\hline YEAR & $\begin{array}{l}\text { Sub-County } \\
\text { overall Mean }\end{array}$ & $\begin{array}{l}\text { Sub-County mathematics } \\
\text { Mean }\end{array}$ & County Overall Mean & $\begin{array}{l}\text { County } \\
\text { Mean }\end{array}$ \\
\hline 2012 & 6.2090 & 4.5200 C- & 5.439 & 3.3890 \\
\hline 2013 & 5.8764 & 3.6787 D & 5.368 & 3.7580 \\
\hline 2014 & 4.9048 & 2.6734 D- & 5.654 & 3.4194 \\
\hline
\end{tabular}

From the Table, there is no account where the mathematics mean score of any year was greater than the sub-county or county mean score. Mathematics KCSE results have therefore remained a drawback, thus pulling the subcounty's KCSE mean grade in the negative direction (KCSE Examination Analysis, (2014).

In secondary school mathematics syllabus, there are areas of mathematics that pose problems to learners. Among them are Compound Proportions and Rates of work, probability, linear programming and Latitudes and Longitudes, among others. Although these areas pose challenges to students, they are very important because they are examined every year in the Kenya Certificate of Secondary Education (KNEC, 2007). To find out the effect of Instructional Practices on Secondary School Students' motivation in Mathematics, the researcher used one of the topics, 'Compound Proportions and Rates of work'. This is one of the topics where questions are set every year in the KCSE as shown in Appendix I. Therefore it is evident that this topic has a great impact on students' academic performance, more so given that mathematics is a compulsory subject. This calls for better understanding of the topic. That's why this research looked at the influence of selected teacher instructional practices in students' motivation in mathematics.

\section{Statement of the problem:-}

The problem currently facing mathematics education in Kenya is the need to improve the students' performance in mathematics. The government of Kenya in collaboration with the Japanese government developed the Strengthening of Mathematics and Science in Secondary Schools Education (SMASSE) in-service program for teachers of science and mathematics in 1998. An essential component of the program is the encouragement of teachers to use instructional approaches that could help improve students' performance in mathematics. There are similar programs by other Non-Governmental Organizations (NGOs) spread throughout the country, for example African Mathematics Initiative (AMI) which was formed in 2011 by lecturers and post graduate students at Maseno University in response to the success of Maseno Mathematics Camp. The Camp was first held in 2010 to enable secondary school students to experience mathematics in an enjoyable and relevant way. However, even with such efforts, performance of students in mathematics continues to decline. It is not known the factors responsible for this observation.

It is not a secret that classrooms are often composed of students from different backgrounds, with different levels of motivation and are also of a wide ability range. This poses challenges to the teacher and calls for a variety of methods and approaches to teaching. There is need for transforming mathematics lessons into students focused environment with meaningful activities that promote efficient learning of mathematics in our classrooms. Perhaps mathematics education in Kenyan secondary schools could greatly benefit from the use of interactive instructional 
practices that enhances the teaching of mathematical concepts, which are either difficult to teach by conventional methods of instruction or where students' motivation is low.

Teachers often state behavioral objectives in their lesson notes when preparing to teach and tell students to use group work when discussing some of the questions. They however fail to realize that behavioral objectives and cooperative group work could better be utilized to stimulate the learners for possible better outcomes. The study therefore investigated the influence of selected teacher instructional practices on students' outcomes in mathematics.

\section{The purpose of the study:-}

The purpose of the study was to investigate the influence of selected instructional strategies on secondary school students' outcomes in mathematics.

\section{Objective of the study:-}

This study was guided by the following objectives;

To find out the influence of selected teacher instructional strategies in students' motivation towards Mathematics.

\section{Hypothesis of the study:-}

This study was guided by the following hypothesis;

$\mathrm{HO}_{1}$ : There is no significant difference in the motivation between students taught Compound Proportions and Rates of Work using BOB, PICT and BO- PICT and those taught using conventional method (TI).

\section{Significance of the study:-}

The purpose of the study was to determine the influence of selected teacher instructional practices on students' motivation in mathematics. This study compares the relative effectiveness of Behavioral Objective-Based (BOB), Peer Instruction enriched with Concept Tests (PICT) as well as both BOB and PICT (BO- PICT) and their counter parts who used the conventional method of instruction.

It has relevance to current mathematics practices for several reasons: First, the findings would assist teachers in seeing and using alternatives in terms of materials, teaching style and activities, content and organization hereof. Second, the findings would help teachers to take into consideration the current interactive practices in the teaching of mathematics. Third, the findings would provide direction to other educators such as Quality and Standards Assurance Officers (QSAO) and curriculum developers in supervision and development of materials that facilitate use of interactive approaches. Thus, an understanding of current practices is relevant to speculations on developing practice.

Thus, the findings would help to determine what is working or is not working within practices, especially those which have hitherto not been well described. It is a means to develop methodology in describing practices. This is necessary for further work on describing how practices change, making it relevant in terms of determining the success of the Curriculum.

In terms of theoretical value, the finding would help in understanding the ramifications involved in interactive instructional approaches; this include the relationship between such approaches as collaborative learning, cooperation learning, problem based learning, project learning, BOB, PICT and BO-PICT and achievement in terms of motivation, cognitive development and positive attitudinal development.

Overall, the findings would thus influence the planning, implementation, and evaluation of actual initiatives in preand in-service training. Thus it is relevant as a basis for actions directed towards developing practice.

\section{Theoretical Framework:-}

The underlying theory of this study is the social constructivism theory. Three broad, interrelated theoretical perspectives on the effects of small-group learning on academic achievement are discussed as motivational, affective, and cognitive. The motivational perspective presumes that task motivation has the greatest impact on the learning process, and that the other processes (such as planning and helping) are driven by individuals' motivated self-interest. 
Motivationalist scholars focus especially on the reward or goal structure under which students operate. Competitive grading and reward systems lead to peer norms that oppose academic effort and academic support. Because one student's success decreases the chances that others will succeed, students may express norms reflecting that "high achievement is for nerds" (Slavin, 1992, pp. 157-158) or may interfere with one another's success. The rationale for implementing group goals is that, if students value the success of the group, they will encourage and help one another to achieve, in contrast to competitive learning environments. Motivationalist theories also tend to emphasize the importance of individual accountability. An underlying assumption is that students might readily interact with and help one another, but without appropriate structure, their help might merely consist of sharing answers and doing each other's work. By holding each group member accountable for learning, the incentive structure supports individuals teaching one another and regularly assessing one another's learning.

Vygotsky (1978) contends that social relations among people underlie all higher cognitive functions and their relations. Also other proponents of constructivism view cooperative group work as an ideal environment for learners to construct knowledge. These include Cobb et al, (1990) who claim that social interaction through cooperative group work constitutes a crucial source of opportunities to learn mathematics through constructing individual's mathematical knowledge. Constructivism asserts that all knowledge is constructed by the individual. Therefore what constitutes knowing is only interpreted as that which the individual conceptualizes. Much of what happens during group work forms the basis of construction and conceptualization of knowledge.

This theoretical framework was therefore relevant to this study because it indicated the factors or variables that influence learning of concepts in mathematics which students usually find abstract and challenging to learn. It also indicated that use of innovative instructional techniques that enable learners to interact during the learning process help learners to overcome such barriers.

\section{Method and Materials:-}

The study adopted pre-test post-test Experimental design with matched experimental and control groups. The design involves a random assignment of intact classes of students to four groups with three groups being Experimental and the other one as Control. Non-equivalent control group design was used in this study because it is not possible to randomly assign subjects to both Experimental and Control groups therefore intact classes were preferred. Selected classes were put into four groups namely Experimental group 1 (E1), Experimental group 2 (E2), Experimental group 3 (E3) and Control group (C). The students in the Control group (C) were taught by the Traditional/conventional method (TI) while in groups E1, E2 and E3 were taught by the BOB, PICT and BO-PICT methods respectively. Table 3.1 illustrates this study design.

Table 3.1: Pre-test Post-test non- equivalent group design

\begin{tabular}{|l|l|l|l|}
\hline Group & Pre-test & Treatment & Post-test \\
\hline C & $\mathrm{O}_{1}$ & $\mathrm{X}$ & $\mathrm{O}_{5}$ \\
E2 & $\mathrm{O}_{2}$ & $\mathrm{X}$ & $\mathrm{O}_{6}$ \\
E3 & $\mathrm{O}_{3}$ & $\mathrm{X}$ & $\mathrm{O}_{7}$ \\
\hline
\end{tabular}

Source: Ary et al (1972)

All the four groups received the pre-test $\left(\mathrm{O}_{1}, \mathrm{O}_{2}, \mathrm{O}_{3} \mathrm{O}_{4}\right)$ to ascertain whether they differed significantly before learning the topic on compound proportions and rates of work. Groups E1, E2 and E3 received the treatment while group C was denied the treatment. Specifically, group E1 was taught by use of Behavioral Objective-Based (BOB) Instructional Strategy, group E 2 was taught by use of Peer Instruction enriched with Concept Tests (PICT), group E3 was taught using both BOB and PICT (BO-PICT) and group C was taught using the TI. After completion of instruction on the topic Compound Proportion and Rates of Work, all the groups then received a post test on all dependent measures. The scores for the pretest and posttest formed the data that were analyzed using both descriptive and inferential statistics.

\section{Results and Discussion:-}

The students' motivation questionnaire (SMQ) which had 16 items was used. Arithmetic mean and standard deviation of the pre- test scores on SMQ were calculated for both Experimental and Control groups and results were as shown in Table 4.15 . 
Table 4.15:- Arithmetic mean and standard deviation on SMQ pre-test scores

\begin{tabular}{|l|l|l|l|l|l|l|l|l|}
\hline SCALE & \multicolumn{2}{|l|}{ E1 } & E2 & E3 & C \\
\hline SAQ & MEAN & S.D & MEAN & S.D & MEAN & S.D & MEAN & S.D \\
\hline & 38.48 & 14.70 & 38.56 & 16.34 & 37.5 & 8.76 & 36.72 & 9.19 \\
\hline
\end{tabular}

An examination of the Table 4.15 reveals that the pre-test mean scores of the Experimental groups E1, E2 and E3 were 38.48, 38.56 and 37.5 respectively while that of the Control group was 36.72 . These results suggest that before the exposure of the students to the lessons on Compound Proportions and Rates of Work the learners had similar motivation. It was necessary to establish if there is any difference between the mean scores of the groups. An ANOVA of the pre-test results was calculated at $\alpha=0.05$ to find out if there was any difference between the mean scores of the groups under investigation and results are recorded in Table 4.16.

Table 4.16:- One way ANOVA on SMQ pre-test results

\begin{tabular}{|c|c|c|c|c|c|}
\hline SOURCE & D.F & S.S & M.S & F-RATIO & Critical value \\
\hline BETWEEN GROUPS & $4-1=3$ & 3886.59 & 1295.53 & \multirow{3}{*}{1.222} & \multirow{3}{*}{3.84} \\
\hline WITHIN GROUPS & $327-4=323$ & 342435.51 & 1060.17 & & \\
\hline TOTAL & 326 & 346322.1 & 2355.7 & & \\
\hline
\end{tabular}

Significance at 0.05 level, critical value1.222<3.84

From Table 4.16, the calculated F-ratio (1.222) was lower than the critical value (1.658). This implies nonexistence of the difference in motivation amongst the groups under study. This indicates that the students' motivation in the learning before exposure to lessons on Compound proportions and rates of work was identical.

In fact, a further analysis of the difference using Scheffe post hoc analysis procedure yielded the trend $\mathrm{C}=$ $\mathrm{E} 1=\mathrm{E} 2=\mathrm{E} 3$ at $\mathrm{p}<0.05$. This indicates nonexistence of significant difference between the mean scores of the groups. It was therefore concluded that there was no significant difference in the motivation of the students prior to the commencement of the learning of Compound Proportions and Rates of Work.

After the implementation of use of BOB, PICT and BO-PICT strategies it can be argued that the mathematics course benefitted all the students since the scores of the students on the SMQ had improved remarkably. Arithmetic mean and standard deviation of post- test scores on SMQ were calculated for both Experimental and Control groups. The comparison of results of the pre-test and post-test scores obtained by the students in all groups on SMQ were summarized in Table 4.18.

Table 4.18:- Comparison of mean scores and mean gains on SMQ.

\begin{tabular}{|l|l|l|l|l|}
\hline Group & No of students & Pre-test mean & Post-test mean & Mean gain \\
\hline E1 & $\mathrm{N}=80$ & 38.48 & 67.67 & 29.19 \\
\hline E2 & $\mathrm{N}=82$ & 38.56 & 69.78 & 31.22 \\
\hline E3 & $\mathrm{N}=84$ & 37.50 & 89.32 & 51.82 \\
\hline C & $\mathrm{N}=82$ & 36.72 & 49.20 & 12.48 \\
\hline
\end{tabular}

It can be noted from results in Table 4.183 that the post- test mean scores for the Experimental groups (E1, E2 and E3) were 67.67, 69.78 and 89.32respectively which were much higher than that of the Control group (49.2). Also, the mean gains were 29.19, 31.22 and 51.82 respectively for the Experimental groups compared to 12.48 for the control group. This indicates that the students who used BO- PICT strategy were more motivated than those ones who used BOB and PICT strategies although all of them were Experimental groups. However, the Control group performed the lowest of the four groups. The high mean scores of the Experimental groups E1, E2 and E3can be attributed to use of BOB, PICT and BO-PICT strategies. From the available statistics therefore, the students in the Experimental groups were much more motivated towards mathematics than those in the Control group.

To provide a clear picture about the effectiveness or otherwise of the BOB, PICT and BO- PICT strategies over traditional method, an ANOVA was calculated to show if there is any significant difference between the mean scores of the groups under investigation and results are recorded in Table 4.21. 
Table 4.21:- One way ANOVA on SMQ post-test results

\begin{tabular}{|c|c|c|c|c|c|}
\hline SOURCE & D.F & S.S & M.S & F-RATIO & Critical value \\
\hline BETWEEN GROUPS & $4-1=3$ & 9496.2 & 3165.4 & \multirow{3}{*}{49.18} & \multirow{3}{*}{3.84} \\
\hline WITHIN GROUPS & $327-4=323$ & 20789.43 & 64.36 & & \\
\hline TOTAL & 326 & 30285.63 & 3229.58 & & \\
\hline
\end{tabular}

Significance at 0.05 level, critical value $49.18>3.84$

It can be observed from Table 4.21 that the calculated F-ratio (49.18) is greater than the critical value (3.84) indicating significant difference in attitude between groups under study. However these results do not show the direction of the difference. As such an independent samples t- test was calculated and results summarized in Table 4.22 .

Table 4.22:- An Independent samples t- test on SMQ post-test results.

\begin{tabular}{|c|c|c|c|c|c|c|c|}
\hline Group & $\mathrm{N}$ & Mean & SD & $\mathrm{DF}$ & Cal t & Crit & Remark \\
\hline E1 & 80 & 67.67 & 8.79 & \multirow[b]{2}{*}{161} & & \multirow[t]{2}{*}{1.658} & \multirow[t]{2}{*}{ Sig difference } \\
\hline $\mathrm{C}$ & 82 & 49.2 & 7.80 & & 14.10 & & \\
\hline E2 & 82 & 69.78 & 7.99 & \multirow[b]{2}{*}{163} & & \multirow[t]{2}{*}{1.658} & \multirow[t]{2}{*}{ Sig difference } \\
\hline $\mathrm{C}$ & 82 & 49.2 & 7.80 & & 16.73 & & \\
\hline E3 & 83 & 89.32 & 7.26 & \multirow[b]{2}{*}{164} & & \multirow[t]{2}{*}{1.658} & \multirow[t]{2}{*}{ Sig difference } \\
\hline $\mathrm{C}$ & 82 & 49.2 & 7.80 & & 34.20 & & \\
\hline E1 & 80 & 67.67 & 8.79 & \multirow[b]{2}{*}{161} & & \multirow[t]{2}{*}{1.658} & \multirow[t]{2}{*}{ No sig difference } \\
\hline E2 & 82 & 69.78 & 7.99 & & 1.597 & & \\
\hline E1 & 80 & 67.67 & 8.79 & \multirow[b]{2}{*}{162} & & \multirow[t]{2}{*}{1.658} & \multirow[t]{2}{*}{ Sig difference } \\
\hline E3 & 83 & 89.32 & 7.26 & & 17.11 & & \\
\hline E2 & 82 & 69.78 & 7.99 & \multirow[b]{2}{*}{161} & & \multirow[t]{2}{*}{1.658} & \multirow[t]{2}{*}{ Sig difference } \\
\hline E3 & 83 & 89.32 & 7.26 & & 16.42 & & \\
\hline
\end{tabular}

The results in Table 4.22 reveal that the $\mathrm{t}$-value for groups $\mathrm{E} 1$ and $\mathrm{E} 2\left(\mathrm{t}_{1,161}\right)=1.597$ are not statistically different. But the $t$-values of groups $E 1$ and $C\left(t_{1,161}\right)=14.10$, groups $E 2$ and $C\left(t_{1,163}\right)=16.73$, groups $E 3$ and $C\left(t_{1,164}\right)$ $=34.20$, groups $\mathrm{E} 1$ and $\mathrm{E} 3\left(\mathrm{t}_{1,163}\right)=17.11$ and groups $\mathrm{E} 2$ and $\mathrm{E} 3\left(\mathrm{t}_{1,162}\right)=16.42$ were statistically different in the post test mean scores in favor of the treatment groups. This is a clear indication that the scores obtained by students who were taught using the BOB, PICT and BO- PICT strategies had a higher mean score and therefore outperformed those ones who used traditional method. However, there was no significant difference between the scores of students who used BOB and PICT strategies, an indication that the two strategies gave statistically the same results. The evidence at hand therefore suggests that the students who were taught mathematics concepts using the BO- PICT strategy achieved higher motivation than those taught using BOB, PICT and traditional method, otherwise traditional method group performed the least of the four groups. It was then concluded that there is a significant difference between the motivation of students who were in the treatment groups (E, E2 and E3) and those in the Control group (C).Moreover, the Scheffe post hoc analysis procedure was further carried out on the data in order to find out where the significant difference lies. The results supported the ones for the t-test and yielded the trend BOPICT (E3)>PICT (E2) BOB > C (TI) for SMQ measure.

\section{Overall Conclusion:-}

The theoretical framework used in the study guided the study in understanding that students' interaction during the learning process enhances learning of mathematical concepts even if such concepts are perceived to be difficult or abstract. Hence the groups that used interactive methods yielded better performance in mathematics. It is the thesis of this study that use of innovative instructional strategies by the teacher that are interactive in orientation enhance students' ability to learn mathematics irrespective of the complexity of the subject matter at hand; this has the advantage of improving and developing students' motivation in learning of mathematics.

\section{Recommendations:-}

From the results of the study, there was no significant difference in general performance on MAT, SAQ and SMQ between the Experimental and Control groups on the pretest results. However after treatment, there was significant differences on motivation questionnaires in favor of the Experimental groups. The evidence at hand therefore 
suggests that the students who were taught the mathematical concepts on Compound Proportions and Rates of Work using BOB, PICT and BO- PICT performed significantly better than those taught using TI.

Evidence abounds that the Conventional teaching method which is the traditional method commonly used in schools, is inadequate for improved students' motivation towards Mathematics. This suggested the need to shift from the conventional method of teaching and embrace some other instructional strategies that have been found to have facilitative effect in promoting students' positive motivation towards Mathematics. The results of this study reveals that BOB, PICT and BO- PICT are potent to bring about better achievement and desirable attitude and motivation towards the subject, although group E3 that used BO- PICT is superior over groups E1, E2 and C that used BOB, PICT and TI strategies. Otherwise the Experimental groups exhibited superiority over the Control group. It is therefore suggested that the teacher can use either strategy or a combination of two to enhance students' positive motivation towards mathematics. In that light of the foregoing, the researcher made the following recommendations:

1. Whenever the matter at hand requires academic achievement, positive students' attitude development towards the subject and a high level of motivation for effective learning, teachers of mathematics should embrace the use of BOB, PICT and BO- PICT.

2. The ministry of Education should embark on a serious campaign through its various arms to enable teachers understand and appreciate that the teaching of mathematics would greatly be enhanced in the event that they use various instructional strategies like BOB, PICT and BO-PICT.

3. There should be in-service training for teachers to enable them learn more so that they are able to use more instructional practices in their lesson delivery to improve intellectual functioning of the students and ensure better performance in their studies.

4. Also, Government should recruit more qualified teachers to be able to cope with the increasing population of secondary school students and initial teacher education should embrace use of various strategies.

5. School administrator should hold seminars and workshops on BO-PICT instructional strategy for teachers so that they can adopt it for effective classroom instruction and students' academic achievement.

6. Vi. The Government need to motivate their teachers to encourage them put in their best to ensure that all students receive proper learning of mathematics through various instructional practices like BOB, PICT and BO-PICT.

\section{References:-}

1. Ary, D., Jacobs, L. C. and Razavieh, A. (1972).Introduction to Research in Education. New York: Holt, Rinehart and Winston.

2. Ball, D. L (1993).Halves pieces and twoths: Constructing representational contexts in teaching fractions:An integration of research (PP.157 - 196). Hillsdale, NJ: Erlbaum.

3. Biggs, J. (1996). Student Learning research and Theory. Where Do We Currently Stand? In G. Gibbs, (Ed), Improving Student Learning Theory and practice. Oxford: Oxford Center for Staff Development. Retrieved October 15, 2006 from http://www.city.londonmet.ac.uk/deliberations/ocsd-pubs/islp-biggs.html

4. Birman, B. F., Desimone, L., Porter, A. C., \&Garet, M. S. (2000). Designing professional development that works. Educational Leadership, 57(8), 28-33.

5. Brasford, J. D. Brophy, S. and Williams, S. (2000). When the Computer Technologies meet the Learning Science: Issues and opportunities.Journal of Applied Developmental Psychology, 21(1), 59-84.

6. Butty J. I. M (2001) Teacher instruction, student attitudes and mathematics performance among $10^{\text {th }}$ and $12^{\text {th }}$ grade black and Hispanic studentsHavarduniversity; provided by pro Quest Information and Learning Company.

7. Chandler, P. \&Sweller, J. (1991). Cognitive load theory and the format of instruction. Cognition and Instruction, 8 (4), 293 - 332.

8. Cobb, P., Wood, T. \&Yackel, E. (1990). Classroom as Learning Environments for Teachers and Researchers. In R. Davis et al (Eds), Constructivist Views on the Teaching and Learning of Mathematics, A JRME Monograph Number 4: Reston, Virginia: NCTM Curriculum 2005, Document (April 1997). Pretoria: National Department of Education

9. Corcoran, T. B. (1995) Transforming professional development for teachers: A guide for state Policy makers. Washington, DC: National Governors Association.

10. Darling- Hammond, L., and McLaughlin, M. W. (1996).Policies that support professional development in an era of reform. In M. W. McLaughlin, and I, Oberman (Eds.), Teacher Learning: New policies, New practices (pp.202-218). New York: Teacher College Press. 
11. Elekwa, U.C.C. (2010). Effects of collaborative teaching/learning strategies on the mathematics Achievement of senior secondary school students in Abia state of Nigeria. Unpublished PhD Thesis submitted to Faculty of Education, University of Port Harcourt.

12. Farrant,J.S. (1994). Principle and practice of education. Singapore. Longman.

13. Hersh, R. (1986). Some proposals for revising the philosophy of mathematics.In T. TYMOCZKO (Ed.), New Direction in the Birkhauser. Philosophy Boston.

14. Hiebert, J. (1999). Relationships between research and the NCTM standards.Journal for Research in Mathematics Education, 30(1), 3-19.

15. Iji, C.O. (2008). Reforming School Mathematics Curriculum in line with global challenges. Proceedings of the 49th Annual Conference of STAN.Pg. 226- 230. Journal of Emerging Trends in Educational Research and Policy Studies (JETERAPS) 4(6):848-854 (ISSN: 2141-6990) 854.

16. Imoko, I. B. \&Agwagha, U. N. (2006). Improving student's Interest in Mathematics Through The Concept Mapping Technique.A focus on Gender. Journal of Research in Curriculum and Teaching (1), 30-31

17. Kenya Institute of Education.(2002) Secondary School Mathematics Syllabus. Nairobi: Government Printers

18. Kenya National Examination Council (KNEC), (2007), 2005 Examination Report. Nairobi, KNEC.

19. Kenya National Examination Council (KNEC), (2008), 1997 Examination Report. Nairobi, KNEC.

20. Kilpatrick, J. Swafford, J: Findel B. (1991) Adding it up: Helping children learn mathematics Washington, DC: National Academy Press.

21. NCTM (2000).Principles and standards for school mathematics. Reston, VA: National Council.

22. NCTM (1991).Curriculum and evaluation standards for school mathematics. Reston, VA: Author of Teachers of Mathematics. National Council of teachers of Mathematics (2000).Principles and standards for school mathematics. Reston, VA: National Council

23. Porter, A. C., \&Brophy, J. E. (1988). Good teaching: Insights from the work of the institute for research on teaching. Educational Leadership, 45(8), 75-84.

24. Prawat, R. (1990). Changing schools by changing teachers' beliefs about teaching and learning (Elementary Subjects Center Series, No. 19). Lansing: Michigan State University, Center for the Learning and Teaching of Elementary Subjects Institute for Research on Teaching.

25. Puma, M. J., Jones, Rock \& Fernandez (1993), Prospects: The Congressionally Mandated Study of Educational Growth and Opportunity. Interim Report. Bethesda, MD: Abt Associates.

26. Roschelle J. Pea R., Hoadly, C. Gordian, D \& Means, B (2000). Changing how and what children learn in school with computer-based technologies. The future of children, 10 (2), 76-101.

27. Roschelle, J \& Singleton, C (2008).Graphing calculators: Enhancing math learning for all students in J. Voogt\& G. Knezek (Eds), Springer.

28. Slavin, R. E. (2003). When and why does cooperative learning increase achievement? Theoretical and empirical perspectives. In R. Hertz-Lazarowitz\& N. Miller (Eds.), Interaction in cooperative groups: The theoretical anatomy of group learning (pp. 145-173). New York: Cambridge University Press.

29. Sparks, D., \&Loucks-Horsley, S. (1989). Five models of staff development for teachers. Journal of Staff Development, 10(4), 40-57.

30. Vygotsky L. S. (1978). Mind in Society the development of higher psychological processes. Cambridge, MA: Harvard University Press.

31. Webb N.M. (1989). Student Interaction and Mathematics Learning in Small Groups.In N. Davidson and R. Dees (Eds), Research in Small Group Cooperative Learning and Mathematics, A Monograph of the Journal for Mathematics Education.

32. Wei, R. C, Darling-Hammond, L. Andree, A. Richardson, N. and Ophanos, S. (2009) Professional Learning in the learning profession: A status report on teacher development in the Unites States and abroad. Dalla TX: National Staff Development Council.

33. Wilkins, J. (2002). The impact of teachers' content knowledge and attitudes on instructional Beliefs and practices.Retrieved October 192009 from Electronic Resources Information Centre (ERIC document No ED 471775). 